\title{
Helicobacter pylori chronic gastritis on patients with premalignant conditions: OLGA and OLGIM evaluation and serum biomarkers performance
}

\author{
Maria Clara Freitas COELHO ${ }^{1,2}$, Henrique Gomes RIBEIRO ${ }^{3}$, Celio Geraldo de Oliveira GOMES ${ }^{3}$, \\ Frederico Passos MARINHO ${ }^{3}$, Alfredo J A BARBOSA ${ }^{1,3}$ and Luiz Gonzaga Vaz COELH0 ${ }^{1,3}$
}

Received: 10 July 2020 Accepted: 15 October 2020

ABSTRACT - Background - H. pylori chronic atrophic gastritis is a premalignant lesion, and its staging, according to OLGA and OLGIM systems aims to identify patients at increased risk of developing gastric cancer and optimize their follow-up. GastroPanel ${ }^{\circledR}$, serum biomarkers panel including pepsinogen I (PGI), pepsinogen II (PGII), Gastrin 17 (G17) and anti- H. pylori antibodies is a noninvasive test for adenocarcinoma risk assessment in chronic H. pylori gastritis patients. Objective - Prospective study to evaluate the concordance between OLGA and OLGIM grading systems, as well as to evaluate GastroPanel's performance in patients with premalignant lesions secondary to H. pylori chronic gastritis in Brazil. Methods - Patients with H. pylori chronic gastritis with premalignant lesions confirmed by histology were recruited from the gastrointestinal clinic of a University Hospital. All participants underwent endoscopic examination with biopsies which were reported according to updated Sydney system and premalignant lesions grading systems (OLGA and OLGIM). Blood samples were collected for biomarkers serological analysis $\left(\right.$ GastroPanel $^{\circledR}$, Biohit, Helsinki, Finland). The cut off values used to define high risk patients were those recommended by the manufacturer: PGI $\leq 30 \mu \mathrm{m} / \mathrm{L}$ and PGI/PGII $\leq 3$. Results - 41 patients were recruited: 28 women, 13 men, mean age 67.3 (47-89, SD: 9.6) years. By OLGA system, were obtained: OLGA 0 (n=1), OLGA I $(\mathrm{n}=7)$, OLGA II $(\mathrm{n}=17)$, OLGA III $(\mathrm{n}=9)$, and OLGA IV $(\mathrm{n}=7)$. By OLGIM system, were obtained: OLGIM 0 ( $\mathrm{n}=14)$, OLGIM I $(\mathrm{n}=5)$, OLGIM II ( $\mathrm{n}=10)$, OLGIM III $(\mathrm{n}=10)$, and OLGIM IV $(\mathrm{n}=2)$. Regarding histological staging among patients staged as low risk (OLGA/OLGIM 0, I and II) and high risk (OLGA/OLGIM III and IV) for gastric cancer development, the concordance rate found between both classifications was $85.4 \%$. Considering high risk patients, those patients thus included in at least one of the systems the final distribution of our sample considered 24 low-risk and 17 high-risk patients for the development of gastric cancer. To determine by GastroPanel ${ }^{\mathbb{}}$ whether the patient would be at low or high risk of developing gastric cancer, PGI showed a sensitivity, specificity and accuracy of 0.47 ( $95 \% \mathrm{CI}$ : $0.26-0.69), 0.67$ (95\% CI: $0.47-0.82$ ), and 0.58 ( $95 \% \mathrm{CI}$ : $0.43-0.72)$, respectively, while PGI/PGII showed sensitivity, specificity and accuracy of 0.06 (95\%CI: $0.01-0.27), 0.83$ (95\%CI: $0.64-0.93$ ) and 0.51 (95\%CI: 0.36-0.66), respectively. Conclusion - The histological classifications OLGA and OLGIM presented a substantial concordance rate among themselves. Simultaneous use of both histological classification systems increased the identification's rate of high-risk patients. Biomarker analysis was not effective to distinguish low to high risk patients in the studied population. Further studies are needed to validate its use in clinical practice in Brazil. HEADINGS - Atrophic gastritis, diagnosis. Helicobacter pylori. Severity of illness index. Biomarkers. Algorithms.

\section{INTRODUCTION}

Helicobacter pylori infection is already recognized as the main etiological factor of chronic gastritis, with an evolutionary potential for the development of peptic ulcer and gastric neoplasms (adenocarcinoma and MALT lymphoma) ${ }^{(1,2)}$. Although its presence evokes a local and systemic immune response, $H$. pylori infection, once acquired, persists indefinitely until it is properly treated. The accurate diagnosis of gastritis associated with $H$. pylori is confirmed by histopathological examination ${ }^{(3)}$.

The sequence $H$. pylori infection $\rightarrow$ chronic gastritis $\rightarrow$ glandular atrophy $\rightarrow$ intestinal metaplasia is a set of associated changes that are very frequently observed. The risk of gastric adenocarcinoma is four to five times higher in patients with severe body atrophy compared to healthy patients. Among patients with severe atrophy of the antrum, there is an 18 times greater risk for development of gastric cancer, reaching 90 times in those with severe atrophy of body and antrum (pangastritis) when compared to healthy people $\mathrm{e}^{(4-9)}$.

Populational studies have been carried out to quantify the risk of this neoplasia in patients with premalignant gastric lesions in western world. In 2008, a cohort conducted in the Netherlands with 92,250 people with premalignant lesions estimated the following risks for developing gastric cancer, within a period of ten years after the initial diagnosis: $0.8 \%$ for people with atrophic gastritis; $1.8 \%$ for

${ }^{1}$ Universidade Federal de Minas Gerais, Faculdade de Medicina, Programa de Pós-Graduação em Ciências Aplicadas à Saúde do Adulto, Belo Horizonte, MG, Brasil. ${ }^{2}$ Faculdade de Ciências Médicas de Minas Gerais, Belo Horizonte, MG, Brasil. ${ }^{3}$ Universidade Federal de Minas Gerais, Instituto Alfa de Gastroenterologia, Hospital das Clínicas, Belo Horizonte, MG, Brasil. Corresponding author: Luiz Gonzaga Coelho. E-mail: Icoelho22@gmail.com 
patients with intestinal metaplasia; $3.9 \%$ for patients with mild to moderate dysplasia and $32.7 \%$ for those with high-grade dysplasia ${ }^{(10)}$. In 2015, a cohort conducted in Sweden analyzed 405,172 individuals who underwent gastric biopsy for non-malignant indications from 1979 to 2011. The findings obtained allowed to predict that $1 / 256$ patients with normal gastric mucosa, 1/85 with chronic gastritis, $1 / 50$ with atrophic gastritis, $1 / 39$ with intestinal metaplasia and $1 / 19$ with dysplasia will develop gastric cancer within 20 years after identification of these lesions ${ }^{(11)}$. Such findings suggest that endoscopic follow-up implementation in patients with marked premalignant lesions could reduce mortality from gastric cancer if cost-benefit analysis proves favorable for a given population.

In order to provide prognostic/therapeutic useful information in premalignant gastric lesions patients management, histological systems have been developed for staging gastritis in this situation. In 2007, the Operative Link for Gastritis Assessment (OLGA) system was developed based on presence, extension and topography (antrum and/or gastric body) of atrophic changes ${ }^{(12)}$. Patients classified as stage III or IV are considered to be at high risk. The Operative link for Gastric Intestinal Metaplasia (OLGIM) Assessment system is also based on the same concept, but only considers the presence, extension and topography of lesions related to intestinal metaplasia ${ }^{(13)}$. The prognostic value of both systems has been documented in different studies, with different samples and populations, and its adoption is recommended by different consensus and guidelines meetings in different regions of the world ${ }^{(14-18)}$.

To avoid excessive performance of invasive and costly procedures such as upper digestive endoscopy, there is a need for searching new non-invasive diagnostic methods, capable of detecting patients at risk of developing gastric cancer, such as patients with different phenotypes chronic gastritis, especially those associated with $H$. pylori infection. This is particularly relevant in countries with a high prevalence and incidence of $H$. pylori infection and gastric cancer in the population.

Pepsinogens, pro-enzymes of pepsin, are classified according to their biochemical and immunological properties into two types: pepsinogen I (PGI) and pepsinogen II (PGII). Both are produced by the gastric mucosa but in different locations. While PGI is produced exclusively by the chief cells and mucous cells of the gastric body, PGII is produced by these cells and also by mucous cells in the cardiac region, pyloric glands, and Brunner glands in the duodenal mucosa. Both pro-enzymes are excreted mainly into the gastric lumen, but a minimal portion (around 1\%) diffuses into the bloodstream and can be measured ${ }^{(19,20)}$. PGI and PGII are increased in patients with $H$. pylori chronic gastritis. However, as atrophy of the body's mucosa occurs, due to the reduction of oxyntic glands, there is a more significant reduction in PGI than in PGII in mild atrophy phase, since this is also produced in other regions of the stomach. Sometimes the mucosa's inflammation associated with $H$. pylori infection is so severe that, even in the presence of atrophy, the levels of PGI and PGII may be elevated ${ }^{(21)}$. To overcome this limitation, the PGI/PGII (RPG) ratio is used, and today is considered the best serological marker for gastric atrophy and already used as a tool for gastric cancer risk screening in Japan and, incipiently, in other countries ${ }^{(22-27)}$. To improve the accuracy of non-invasive diagnosis of gastric atrophy, the addition of other biomarkers to pepsinogens has been suggested. By associating anti-H. pylori antibodies to pepsinogens dosage (ABCD method), Asian researchers have shown that the method has the potential to stratify healthy adults from those at increased risk of developing gastric cancer ${ }^{(28)}$. Another association of biomarkers recently described (GastroPanel ${ }^{\circledR}$, Biohit, Helsinki, Finland), involves, in addition to the determination of pepsinogens and anti$H$. pylori antibodies, the determination of gastrin-17 (G17), all of them through the collection of a single blood sample. Two recent meta-analyses have evaluated the performance of GastroPanel ${ }^{\circledR}$ : Syrjänen $\mathrm{K}^{(29)}$ analyzed the results of 8,654 patients from different countries, having found sensitivity of $70.2 \%$ and specificity of $93.9 \%$ in the diagnosis of body's atrophic gastritis and sensitivity of $53.8 \%$ and specificity of $84.1 \%$ in the diagnosis of antrum atrophic gastritis. Zagari RM, et al. ${ }^{(30)}$ analyzed 20 studies involving 4,241 participants, finding similar sensitivity $(70.4 \%)$ for the diagnosis of body's atrophic gastritis and sensitivity of $65.4 \%$ for the diagnosis of antrum atrophic gastritis.

There are still few studies that relate levels of pepsinogens to the diagnosis of gastric atrophy in Latin America countries ${ }^{(31,32)}$. The aim of this study was to perform a prospective study to evaluate the concordance between OLGA and OLGIM systems, as well as GastroPane ${ }^{\circledR}$ performance in patients with premalignant lesions secondary to $H$. pylori chronic gastritis in Brazil.

\section{METHODS}

A consecutive series of adult patients of both sexes, with $H$. pylori chronic gastritis with associated premalignant conditions on histology, was recruited from November/2016 to April/2019 at the upper gastrointestinal outpatient clinic of University Hospital. Patients were excluded if they had coagulation disorders that should avoid gastric biopsies or if they had acute illnesses and indication for surgery or urgent treatment to control their symptoms. Were also excluded patients who used antibiotics on the 30 days preceding upper digestive endoscopy, proton pump inhibitor (PPI), and histamine $\mathrm{H} 2$ receptor antagonist on the 10 days preceding upper digestive endoscopy, and patients with chronic atrophic gastritis from proven autoimmune etiology.

All patients included in the study answered a pre-established clinical questionnaire and, after agreeing to participate in the study and signing the informed consent form, were submitted to blood collection for the serological panel and upper digestive endoscopy.

\section{Serological panel (GastroPanel ${ }^{\circledR}$ )}

Immediately before endoscopic examination, a cubital vein blood sample ( $4 \mathrm{~mL}$ ) was collected, and after centrifugation, the plasma was immediately stored into a $-80^{\circ} \mathrm{C}$ freezer. All samples were processed for ELISA readings using Sprinter XL equipment (Euroimmun, Germany). Each marker was analyzed on an individual microplate, and the device's software was programmed according to the manufacturer's instructions, who provided the following reference values: pepsinogen I: $30-160 \mu \mathrm{m} / \mathrm{L}$; pepsinogen II: $3-15 \mu \mathrm{m} / \mathrm{L}$; gastrin 17: 1-7 pmol/L; Helicobacter pylori IgG ELISA: $<30$ EUI $=$ negative. For the classification of patients into low and high risks for the development of gastric cancer, the following values were considered: $\mathrm{PGI} \leq 30$ : high-risk patient; PGI $>30$ : low-risk patient; $\mathrm{PGI} / \mathrm{PG} \mathrm{II} \leq 3$ : high-risk patient; $\mathrm{PGI} / \mathrm{PGII}>$ 3: low-risk patient.

\section{Upper digestive endoscopy with gastric biopsies}

During endoscopy, six gastric biopsies were collected (two biopsies from gastric antrum, one biopsy from angular notch and three from gastric body). All biopsies were fixed in 10\% 
Coelho MCF, Ribeiro HG, Gomes CGO, Marinho FP, Barbosa AJA, Coelho LGV Helicobacter pylori chronic gastritis on patients with premalignant conditions: OLGA and OLGIM evaluation and serum biomarkers performance

formaldehyde and included in paraffin blocks separately and reported according to the Updated Sydney System for Gastritis Classification $^{(33)}$. The histological study of the gastric mucosa was performed in histological sections of $4 \mu \mathrm{m}$ thick by a single gastrointestinal pathologist. The histological stains used were hematoxylin-eosin (HE) for histopathological analysis and Giemsa for $H$. pylori infection presence. All patients had their histological findings staged according to the OLGA ${ }^{(34)}$ and OLGIM ${ }^{(13)}$ systems.

\section{Statistics}

Descriptive statistics techniques were used. Continuous variables were compared using Student's $t$-test, Mann-Whitney test (non-parametric data), and the chi-square test was used to quantitatively assess the relationship between results obtained. Considering the histological results of the OLGA-OLGIM set as the gold standard, sensitivity, specificity, positive predictive value, negative predictive value, accuracy and 95\% confidence interval (CI) were calculated for the results obtained through serological biomarkers. Kappa values and 95\%CI were determined to concordance analysys between OLGA and OLGIM systems. The Confidence Interval Analysis (CIA) program was used to calculate the confidence intervals using Wilson's method. Statistical significance was recognized for values of $P<0.05$. All statistical analyzes were performed using the MINITAB statistical package (Minitab Inc., USA) version 16, Excel (Office 10). The study was approved by the Universidade Federal de Minas Gerais Research Ethics Committee. For sampling, the number of subjects required as low risk to develop gastric cancer (OLGA and OLGIM I or II) and high risk (OLGA or OLGIM III or IV) was calculated based on studies showing expected values for GastroPanel ${ }^{\circledR}$ reported in previous studies ${ }^{(29)}$. It was estimated with $80 \%$ power, 172 and 61 patients from low risk and high risk, respectively. As the amount of patients needed would take too long to be recruited, it was adopted a convenience, not probabilistic sample composed by the number of patients suitable for this preliminar study included during the two years and six months study period.

\section{RESULTS}

Initially, 46 patients were recruited and five patients were excluded: one by using oral anticoagulant, two due to thrombocytopenia, one due to erroneous inclusion (proven autoimmune gastritis), and one patient for refusing to participate in the study. Thus, a total of 41 patients participated in the study, and their demographic characteristics can be seen in TABLE 1 .

\section{Histological findings}

TABLE 2 shows the observed distribution of all patients according to the histological staging of gastritis OLGA and OLGIM. FIGURE 1 shows concordance's rate between both histological systems regarding the staging of patients as low and high risk of the development gastric cancer. It can be seen that, among the 41 patients in the study, 24 were classified as low risk by both systems, 11 were classified as high risk by both systems and six patients presented discordant classifications, thus conferring 0.678 (95\%CI: $0.440-0.916)$ kappa value and $85.4 \%$ concordance rate. Considering high-risk patients those patients thus included in at least one the histological staging systems, the final distribution of our sample considered 24 patients at low risk and 17 as high risk for the development of gastric cancer. Based on this distribution,
TABLE 1. Demographic characteristics of the 41 patients in the study.

$\begin{array}{lc}\text { Sex: male/female } & 13 / 28 \\ \text { Mean age (years): (SD) } & 67.3(9.6) \\ \text { Mean BMI }\left(\mathrm{kg} / \mathrm{m}^{2}\right):(\mathrm{SD}) & 26.8(5.1) \\ \text { Alcoholism: n }(\%) & 6(15) \\ \text { Smoking: n (\%) } & 8(20) \\ \text { Education: n (\%) } & \\ \text { Elementary School } & 19(46.3) \\ \text { High School } & 19(46.3) \\ \text { Higher Education } & 3(7.4) \\ \text { Comorbidities: } \mathrm{n}(\%) & 1(2.4) \\ \text { None } & 29(70.7) \\ \text { Hypertension } & 13(31.7) \\ \text { Diabetes mellitus } & 3(7.3) \\ \text { NSAIDs: n (\%) } & 22(53.7) \\ \text { Dyspepsia: n (\%) } & 5(12.2) \\ \text { Family history of gastric cancer: } \mathrm{n}(\%) & \end{array}$

SD: standard deviation; BMI: body mass index; NSAIDs: nonsteroidal anti-inflammatory drugs.

TABLE 2. Distribution of patients according to OLGA and OLGIM histological grading systems $(n=41)$.

\begin{tabular}{lccccc}
\hline & $\begin{array}{c}\text { OLGA } \\
0\end{array}$ & $\begin{array}{c}\text { OLGA } \\
\text { I }\end{array}$ & $\begin{array}{c}\text { OLGA } \\
\text { II }\end{array}$ & $\begin{array}{c}\text { OLGA } \\
\text { III }\end{array}$ & $\begin{array}{c}\text { OLGA } \\
\text { IV }\end{array}$ \\
\hline & 1 & 7 & 17 & 9 & 7 \\
$\begin{array}{l}\text { Number of } \\
\text { patients }\end{array}$ & $\begin{array}{c}\text { OLGIM } \\
0\end{array}$ & $\begin{array}{c}\text { OLGIM } \\
\text { I }\end{array}$ & $\begin{array}{c}\text { OLGIM } \\
\text { II }\end{array}$ & $\begin{array}{c}\text { OLGIM } \\
\text { III }\end{array}$ & $\begin{array}{c}\text { OLGIM } \\
\text { IV }\end{array}$ \\
& 14 & 5 & 10 & 10 & 2
\end{tabular}

$\overline{\text { OLGA: Operative Link for Gastritis Assessment; OLGIM: Operative link for Gastric Intestinal }}$ Metaplasia.

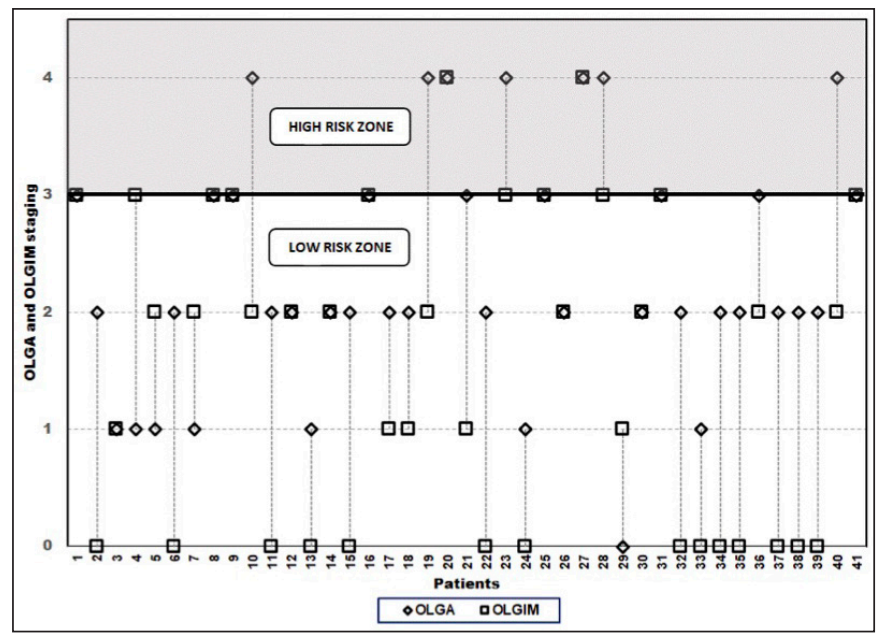

FIGURE 1. OLGA and OLGIM staging systems in 41 patients of the study. 
TABLE 3 shows that the two groups do not present statistically significant differences on demographic variables, except for gender variable, with the female gender being predominant in high-risk group $(P=0.02)$.

TABLE 3. Comparison of demographic characteristics in the 41 patients classified by the OLGA and OLGIM gastritis grading systems, as low and high risk for developing gastric cancer.

\begin{tabular}{lccc}
\hline Variables & $\begin{array}{c}\text { OLGA or } \\
\text { OLGIM } \\
\text { Low risk } \\
(\mathbf{n}=24)\end{array}$ & $\begin{array}{c}\text { OLGA and/ } \\
\text { or OLGIM } \\
\text { High risk } \\
(\mathbf{n}=17)\end{array}$ & $P$-value \\
\hline Mean age (years): SD & $65.7(10.1)$ & $69.6(8.6)$ & $0.36^{*}$ \\
Mean BMI $\left(\mathrm{kg} / \mathrm{m}^{2}\right)$ : SD & $26.7(4.4)$ & $26.8(6.1)$ & $0.75 *$ \\
Sex: male/female & $11 / 13$ & $2 / 15$ & $0.02 * *$ \\
Education: ES/H & $12 / 12$ & $7 / 10$ & $0.58^{* *}$ \\
Smoking: no/yes & $19 / 5$ & $14 / 3$ & $0.80^{* *}$ \\
Alcoholism: no/yes & $21 / 3$ & $14 / 3$ & $0.65 * *$ \\
$\begin{array}{l}\text { Family history of gastric } \\
\text { cancer: no/yes }\end{array}$ & $22 / 2$ & $14 / 3$ & $0.37 * *$ \\
NSAIDs: no/yes & $22 / 2$ & $16 / 1$ & $0.80^{* *}$ \\
$\begin{array}{l}\text { Previous } H . \text { pylori } \\
\text { treatment: no/yes }\end{array}$ & $2 / 22$ & $4 / 13$ & $0.17 * *$ \\
$\begin{array}{l}\text { H. pylori at histology: } \\
\text { no/yes }\end{array}$ & $18 / 6$ & $16 / 1$ & $0.11 * *$ \\
Dyspepsia: no/yes & $12 / 12$ & $7 / 10$ & $0.58^{* *}$ \\
\hline
\end{tabular}

SD: standard deviation; OLGA: Operative Link for Gastritis Assessment; OLGIM: Operative link for Gastric Intestinal Metaplasia; ES: Elementary School; H: High School or Higher Education. *Mann Whitney test; **chi-square test.

\section{Serological biomarkers}

TABLE 4 shows PGI, PGI/PGII, and Gastrin-17 values obtained in patients with low and high risks for the development of gastric cancer by OLGA system, OLGIM system, and by OLGAOLGIM set. No statistically significant differences were found in any of comparative analyses performed.

TABLE 5 shows the accuracy determinations of PGI biomarker and PGI / PGII ratio to determine whether the patient would be at low or high risk for developing gastric cancer. The PGI showed a sensitivity of $0.50,0.42$, and 0.47 for the OLGA, OLGIM and OLGA-OLGIM set, respectively. The observed specificity was 0.68 , 0.62 , and 0.67 for the OLGA, OLGIM and OLGA-OLGIM set, respectively and accuracy of $0.61,0.56$, and 0.58 for the OLGA, OLGIM, and OLGA-OLGIM set, respectively. The PGI / PGII showed sensitivity of $0.06,0.00$ and 0.06 for the OLGA, OLGIM, and OLGA-OLGIM set, respectively. The observed specificity was $0.84,0.83$, and 0.83 for the OLGA, OLGIM, and OLGA-OLGIM set, respectively, and accuracy of $0.49,0.58$ and 0.51 for the OLGA, OLGIM, and OLGA-OLGIM set, respectively.

\section{Helicobacter pylori}

FIGURE 2 shows previous $H$. pylori infection treatment information and histology and serology results. Only one patient had no informed previous infection's treatment and tested negative both by histology and serology.
TABLE 4. Comparative analysis of PGI levels, PGI / PGII, and Gastrin-17 observed in patients classified according to the risk of developing gastric cancer by the OLGA, OLGIM and by the OLGA and OLGIM set.

\begin{tabular}{|c|c|c|c|}
\hline Variable & $\begin{array}{c}\text { OLGA } \\
\text { Low risk } \\
(\mathrm{n}=25)\end{array}$ & $\begin{array}{c}\text { OLGA } \\
\text { High risk } \\
(\mathrm{n}=16)\end{array}$ & $P$-value* \\
\hline PG I $(\mu \mathrm{g} / \mathrm{L})$ : mean $(\mathrm{SD})$ & $64.2(67.6)$ & $57.8(64.9)$ & 0.640 \\
\hline PGI/PGII: mean (SD) & $17.9(13.6)$ & $17.8(7.2)$ & 0.659 \\
\hline $\begin{array}{l}\text { Gastrin-17 }(\mathrm{pmol} / \mathrm{L}) \\
\text { mean }(\mathrm{SD})\end{array}$ & $12.4(11.8)$ & $29.5(28.9)$ & 0.317 \\
\hline Variable & $\begin{array}{c}\text { OLGIM } \\
\text { Low risk } \\
(\mathrm{n}=29)\end{array}$ & $\begin{array}{c}\text { OLGIM } \\
\text { High risk } \\
(\mathrm{n}=12)\end{array}$ & $P$-value \\
\hline PG I $(\mu \mathrm{g} / \mathrm{L})$ : mean $(\mathrm{SD})$ & $64.2(73.0)$ & $50.1(44.3)$ & 0.808 \\
\hline PGI/PGII: mean (SD) & $17.4(13.4)$ & $18.8(4.1)$ & 0.398 \\
\hline $\begin{array}{l}\text { Gastrin-17 }(\mathrm{pmol} / \mathrm{L}) \\
\text { mean }(\mathrm{SD})\end{array}$ & $14.7(18.4)$ & $9.4(19.3)$ & 0.086 \\
\hline Variable & $\begin{array}{l}\text { OLGA and } \\
\text { OLGIM } \\
\text { Low risk } \\
(\mathrm{n}=24)\end{array}$ & $\begin{array}{c}\text { OLGA and/or } \\
\text { OLGIM } \\
\text { High risk } \\
(\mathrm{n}=17)\end{array}$ & $P$-value \\
\hline PG I $(\mu \mathrm{g} / \mathrm{L})$ : mean $(\mathrm{SD})$ & $65.4(68.8)$ & $56.4(63.1)$ & 0.624 \\
\hline PGI/PGII: mean (SD) & $17.9(13.9)$ & $17.8(6.9)$ & 0.701 \\
\hline $\begin{array}{l}\text { Gastrin-17 }(\mathrm{pmol} / \mathrm{L}) \\
\text { mean }(\mathrm{SD})\end{array}$ & $9.3(10.6)$ & $18.6(25.5)$ & 0.317 \\
\hline
\end{tabular}

OLGA: Operative Link for Gastritis Assessment; OLGIM: Operative link for Gastric Intestinal Metaplasia; SD: standard deviation. *Mann Whitney test.

TABLE 5. Accuracy measures of the PGI and PGI/PGII considering the OLGA, OLGIM gastritis grading systems and by the OLGA and OLGIM set.

\begin{tabular}{|c|c|c|c|c|}
\hline & \multirow{2}{*}{$\begin{array}{l}\text { Accuracy } \\
\text { measures }\end{array}$} & \multicolumn{3}{|c|}{ Gastritis grading systems } \\
\hline & & OLGA & OLGIM & $\begin{array}{l}\text { OLGA and } \\
\text { OLGIM }\end{array}$ \\
\hline \multirow{5}{*}{ PGI } & $\begin{array}{l}\text { Sensitivity } \\
(95 \% \mathrm{CI})\end{array}$ & $\begin{array}{c}0.50 \\
(0.28-0.72)\end{array}$ & $\begin{array}{c}0.42 \\
(0.19-0.68)\end{array}$ & $\begin{array}{c}0.47 \\
(0.26-0.69)\end{array}$ \\
\hline & $\begin{array}{l}\text { Specificity } \\
(95 \% \mathrm{CI})\end{array}$ & $\begin{array}{c}0.68 \\
(0.48-0.83)\end{array}$ & $\begin{array}{c}0.62 \\
(0.44-0.77)\end{array}$ & $\begin{array}{c}0.67 \\
(0.47-0.82)\end{array}$ \\
\hline & $\begin{array}{c}\text { PPV } \\
(95 \% \mathrm{CI})\end{array}$ & $\begin{array}{c}0.50 \\
(0.28-0.72)\end{array}$ & $\begin{array}{c}0.31 \\
(0.14-0.56)\end{array}$ & $\begin{array}{c}0.50 \\
(0.28-0.72)\end{array}$ \\
\hline & $\begin{array}{c}\mathrm{NPV} \\
(95 \% \mathrm{CI})\end{array}$ & $\begin{array}{c}0.68 \\
(0.48-0.83)\end{array}$ & $\begin{array}{c}0.72 \\
(0.52-0.86)\end{array}$ & $\begin{array}{c}0.64 \\
(0.44-0.80)\end{array}$ \\
\hline & $\begin{array}{l}\text { Accuracy } \\
(95 \% \text { CI })\end{array}$ & $\begin{array}{c}0.61 \\
(0.46-0.74)\end{array}$ & $\begin{array}{c}0.56 \\
(0.41-0.70)\end{array}$ & $\begin{array}{c}0.58 \\
(0.43-0.72)\end{array}$ \\
\hline \multirow{5}{*}{$\begin{array}{l}\text { PGI/ } \\
\text { PGII }\end{array}$} & $\begin{array}{l}\text { Sensitivity } \\
(95 \% \mathrm{CI})\end{array}$ & $\begin{array}{c}0.06 \\
(0.01-0.28)\end{array}$ & $\begin{array}{c}0.00 \\
(0.00-0.24)\end{array}$ & $\begin{array}{c}0.06 \\
(0.01-0.27)\end{array}$ \\
\hline & $\begin{array}{l}\text { Specificity } \\
(95 \% \text { CI })\end{array}$ & $\begin{array}{c}0.84 \\
(0.65-0.94)\end{array}$ & $\begin{array}{c}0.83 \\
(0.65-0.92)\end{array}$ & $\begin{array}{c}0.83 \\
(0.64-0.93)\end{array}$ \\
\hline & $\begin{array}{c}\text { PPV } \\
(95 \% \mathrm{CI})\end{array}$ & $\begin{array}{c}0.20 \\
(0.04-0.62)\end{array}$ & $\begin{array}{c}0.00 \\
(0.00-0.43)\end{array}$ & $\begin{array}{c}0.20 \\
(0.04-0.62)\end{array}$ \\
\hline & $\begin{array}{c}\text { NPV } \\
(95 \% \mathrm{CI})\end{array}$ & $\begin{array}{c}0.58 \\
(0.42-0.73)\end{array}$ & $\begin{array}{c}0.68 \\
(0.50-0.80)\end{array}$ & $\begin{array}{c}0.56 \\
(0.40-0.70)\end{array}$ \\
\hline & $\begin{array}{l}\text { Accuracy } \\
(95 \% \text { CI })\end{array}$ & $\begin{array}{c}0.49 \\
(0.34-0.63)\end{array}$ & $\begin{array}{c}0.58 \\
(0.43-0.72)\end{array}$ & $\begin{array}{c}0.51 \\
(0.36-0.66)\end{array}$ \\
\hline
\end{tabular}

OLGA: Operative Link for Gastritis Assessment; OLGIM: Operative link for Gastric Intestinal Metaplasia; PGI: pepsinogen I; PGII: pepsinogen II; PPV: positive predictive value; NPV: negative predictive value. 


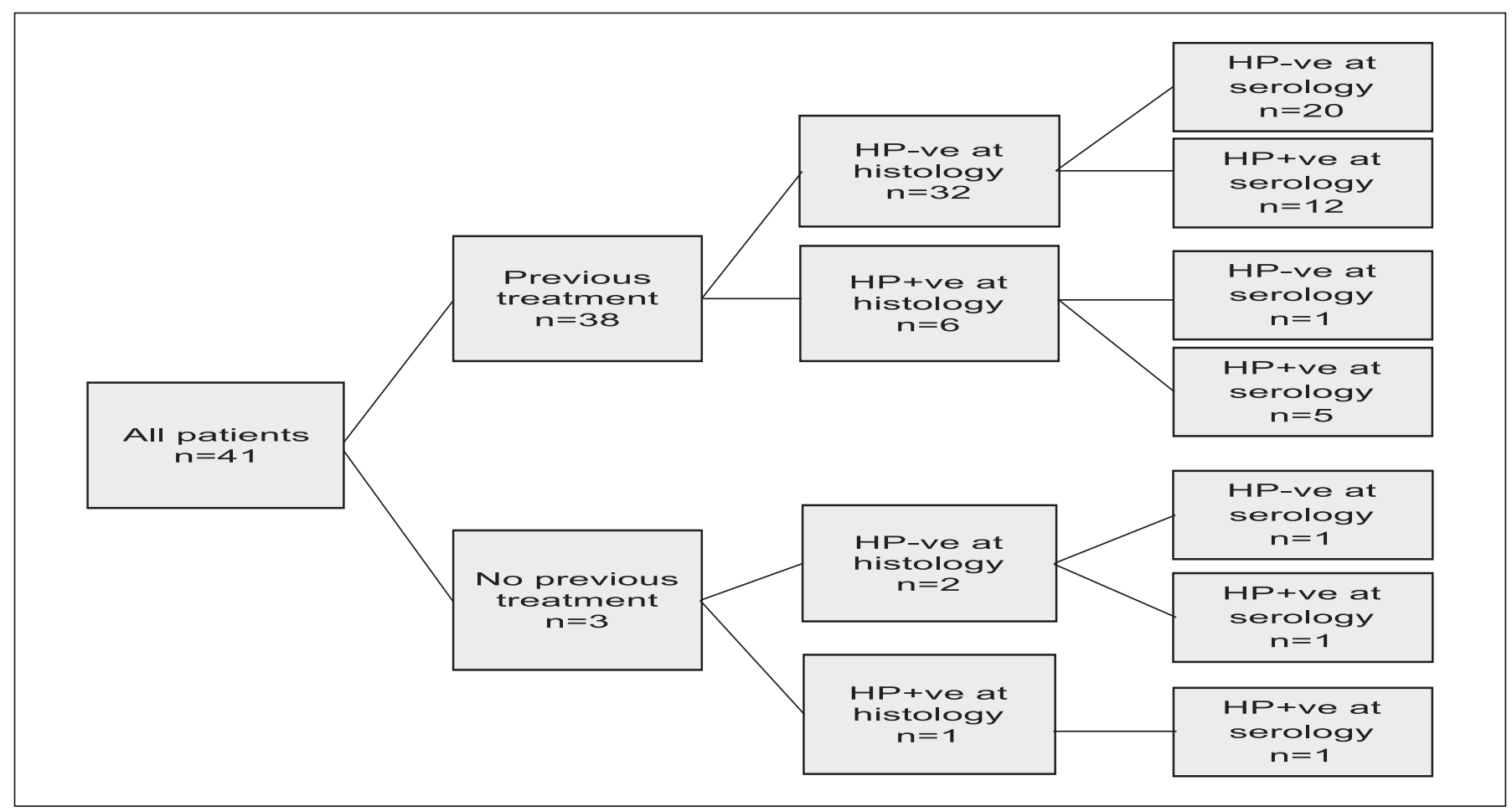

FIGURE 2. Findings regarding $H$. pylori infection $(\mathrm{n}=41)$ on previous treatment of the infection, the search for bacteria during histological examination and the serological findings of the presence of anti-H. pylori antibodies.

\section{DISCUSSION}

Our study's findings, obtained from 41 patients with $H$. pylori chronic gastritis and premalignant lesions, showed that $41.4 \%$ were high risk histologically classified. Although a recent systematic review about the prevalence of advanced gastric premalignant lesions in countries with low/moderate gastric cancer incidence (like Brazil), estimate 7.3\% incidence (95\% CI: 5.6-9.05) for atrophic gastritis and 7.7\% (95\% CI: 3.2-12.1) for intestinal metaplasia ${ }^{(35)}$, these findings can be justified by origin bias, since our patients were recruited from a tertiary service, specialized on assisting patients with chronic esophageal-gastric-duodenal diseases. Besides the high mean age of patients, 67.3 (SD: 9.6) years, is another contributory factor, considering that premalignant lesions prevalence is three times higher in individuals over 40 when compared with those younger than 40 years old ${ }^{(35)}$.

The analysis of OLGA and/ or OLGIM systems performance as a protocol to obtain gastric biopsies capable of increasing the premalignant lesion's detection yield has shown promising results. In 2018, Yue H, et al. ${ }^{(36)}$, carried out a systematic review and metaanalysis assessing the association between OLGA and OLGIM systems and the risk of gastric cancer, as well as the strength of this association. 2,700 patients included in six case-control studies (OLGA system used in all and OLGIM system in three) and two cohorts (one including OLGA system and another OLGIM system) were analyzed. Regarding the OLGA system, the analysis of cohort studies revealed that individuals staged as high risk had a 27.7 times greater risk of developing gastric cancer compared to their counterparts. The analysis of the only cohort analyzing the OLGIM system showed that patients classified as high-risk had
RR 16.67 (95\%CI: 0.80-327.53) for the development of gastric cancer or gastric dysplasia. The authors conclude that close and frequent monitoring of patients classified as high risk in OLGA or OLGIM systems is necessary to facilitate early diagnosis of gastric cancer.

Two recent cohorts have also analyzed the role of OLGA and OLGIM systems in assessing the concordance between intensity of pre-neoplastic lesions and gastric cancer development risk. Rugge M, et al. ${ }^{(37)}$, in 2018, in Italy, followed 7,436 patients who underwent upper digestive endoscopy due to dyspeptic complaints. Histological evaluation was performed according to the OLGA system (OLGA 0: 80\%, OLGA I: 12.6\%, OLGA II: 4.3\%, OLGA III: $2.0 \%$ and OLGA IV: $0.3 \%$ ) and patients were followed for a median period of 6.6 years. 28 out of 7,436 patients included in the study developed neoplastic lesions: 17 patients with low-grade dysplasia, four with high-grade dysplasia, and seven with gastric cancer. According to OLGA staging at the time of study inclusion, 1/28 cases of gastric neoplasia were classified as OLGA 0 , 2/28 patients as OLGA I, 3/28 patients as OLGA II, 17/28 patients as OLGA III and 5 / 28 as OLGA IV. Multivariate analysis of the study including gender, age, $H$. pylori presence and OLGA system determined upon admission to the study revealed, among these variables, only OLGA system as a predictor of neoplastic progression: being OLGA III: HR: 712.4 (95\%CI: 92.543-5484.5) and OLGA IV: HR: 1450.7 (95\%CI: 166.7-12626.0). In 2019, Den Hollander WJ et al. ${ }^{(38)}$, prospectively analyzed 279 Dutch and Norwegian patients included in the study due to histological evidence of atrophic gastritis, intestinal metaplasia and/or dysplasia of the gastric mucosa at gastroscopy and staged according to the OLGIM system. After an average follow-up period of 57 months, 
4/279 (1.4\%) patients developed high-grade adenoma/dysplasia or gastric cancer. The progression to neoplasia occurred in one patient in low-risk group according to OLGIM system and in two patients in high-risk group $(P=0.11)$. The authors conclude that, even in regions with a low incidence of gastric cancer, follow-up programs are able to detect gastric cancer in potentially curable stages, with a risk of neoplastic progression of $0.3 \%$ per year.

In our study, the two histological staging systems, OLGA and OLGIM, were concordant in $85.4 \%$ (kappa value: 0.678 ) and disagreement in $14.6 \%(n=6)$. The simultaneous use of both histological classification systems allowed 17 patients to be identified as high risk, 11 through identification by both systems, with five additional patients classified as high risk only by the OLGA system and one additional patient classified as high risk only by the OLGIM system. These findings coincide with those observed in a recent study and meta-analysis ${ }^{(36,37)}$ suggesting that, although the OLGIM system provides easier identification of intestinal metaplasia and better interobserver reproducibility, it fails to identify an appreciable number of high-risk patients. Therefore, it is suggested that, for an accurate prediction of gastric cancer risk, both systems should be used simultaneously in daily pathological practice.

Studies have been performed to evaluate the concordance between OLGA and OLGIM systems in the staging of premalignant gastric lesions and their progression to gastric cancer. Both were developed from the Sydney System for classification and grading of gastritis ${ }^{(33)}$, which is dependent on the histopathological findings from endoscopic biopsies. One limitation attributed to the OLGA system is related to the fact that its main parameter is the intensity and extent of atrophic gastritis, with studies by North American ${ }^{(39)}$ and European ${ }^{(40)}$ pathologists showing that interobserver agreement is low, even when using a visual analog scale. On the other hand, the OLGIM system, when proposing the use of intestinal metaplasia, the next step of the Pelayo Correa cascade for the development of gastric cancer ${ }^{(4)}$, offers a more easily identifiable marker in the gastric mucosa and, consequently, with greater interobserver agreement ${ }^{(33,41)}$. Isajevs $\mathrm{S}$, et al.$^{(42)}$, in 2014, compared the interobserver agreement between general pathologists and gastrointestinal specialized pathologists in the staging of gastritis by OLGA and OLGIM systems in 835 patients. The OLGIM system provided the highest interobserver agreement, however it was observed that a substantial proportion of high-risk individuals would not be detected if only the OLGIM system was adopted. In 2018, Mera RM, et al. ${ }^{(43)}$, in a follow-up study for up to 16 years of 795 patients with pre-neoplastic gastric lesions, demonstrated that the probability of progression to gastric cancer among patients classified as high and low risk by the OLGIM system was twice as high as that observed in patients classified as high and low risk by the OLGA system.

In our study, the analysis of the demographic variables of patients classified in OLGA and OLGIM systems together as high and low risks showed statistical significance only for the gender variable, with the female gender being predominant in the highrisk population $(P=0.02)$. The small sample of this study turns difficult to make greater inferences, requiring studies with greater sample power.

Our findings related to $H$. pylori infection showed that $38 / 41$ $(92.7 \%)$ patients underwent eradication treatment, with $6 / 38$ $(15.7 \%)$ still harboring the bacteria. The findings of $84.2 \%$ cure rate are consistent with $H$. pylori eradication rates obtained from the Brazilian and Latin American populations, in different studies $^{(44)}$. A single patient in the study who denied previous anti- $H$. pylori treatment and whose histological and serological studies were negative showed a histological pattern of atrophic gastritis classified as OLGA IV. It is interesting to note that this situation has been described by ABCD Japanese serological classification, as being in group $\mathrm{D}$, with a high risk for gastric cancer in which atrophy is so intense that it would turn gastric mucosa uninhabitable for H. pylori. ${ }^{(45)}$.

For the prediction of premalignant changes identified by histology the analysis of PGI biomarkers and PGI/PGII ratio, based on OLGA-OLGIM set, showed $47 \%$ sensitivity for PGI $(95 \% \mathrm{CI}$ : 26-69) and 67\% specificity (95\%CI: 47-82), and for PGI/PGII ratio, the sensitivity was $6 \%(95 \% \mathrm{CI}: 1-27)$ and $83 \%$ specificity (95\%CI: 64-93). Regarding G-17 determination, based on OLGALGIM set, the mean values obtained in patients classified as low and high risk had no statistically significant difference from each other opposing a previous meta-analysis, with 13 studies, which described a $82 \%$ accuracy of G17 in identifying patients with chronic atrophic gastritis ${ }^{(46)}$. The values obtained here, unsatisfactory as discriminating patients with low and high risk of developing gastric cancer have also been observed in other studies. A prospective, multicenter, Spanish study analyzed 91 dyspeptic patients with the same serological panel used here. The values of PGI and PGI/ PGII ratio did not show statistically significant differences when compared to histology, with 50\% sensitivity (95\%CI: 39-61) and $80 \%$ specificity $(95 \% \text { CI: } 71-88)^{(47)}$. In Peru, Calarossi A, et al. ${ }^{(48)}$ found sensitivity of $54 \%$ and specificity of $68 \%$ of serological panel to identify chronic atrophic gastritis. Recent meta-analysis analyzed the performance of the GastroPanel ${ }^{\circledR}$ in 20 studies including 4,241 patients and observed sensitivity of $74.7 \%$ (95\%CI: $62-84.3)$ and specificity of $95.6 \%$ (95\% CI: 92.6-97.4) of the serological panel to identify patients with chronic atrophic gastritis ${ }^{(30)}$. Another systematic review and meta-analysis study for the accuracy analysis of serological panel, including 27 studies, identified a sensitivity of $53.8 \%$ and specificity of $84.1 \%$ of the method to identify chronic atrophic gastritis ${ }^{(29)}$.

Our results showed that GastroPanel ${ }^{\circledR}$ was not effective in identifying patients with pre-neoplastic lesions, and one of the factors that may have interfered on results is the mean age $(67.3$ years) of our studied population. In a review article Miki $\mathrm{K}^{(25)}$, in 2006, considers sex, age, $H$. pylori infection, smoking and alcohol consumption as factors capable of influencing serum levels of pepsinogens and suggests that lower levels of pepsinogen tests found in the elderly population can be attributed to atrophic changes in the gastric mucosa and not exactly to the age itself. A recent Japanese guideline on the management of Helicobacter pylori infection also highlights the possibility that patients with gastric atrophy, mainly over 65 years of age, with an ongoing or past infection, often yield false-negative results on pepsinogen tests $^{(49)}$. In this context, we assessed the presence of an association between advanced age ( $\geq 65$ years) and higher levels of PGI and failed to find any statistically significant difference between the compared groups.

The present study has limitations that deserve consideration. Initially, although the study covered all patients with $H$. pylori chronic gastritis and associated pre-malignant lesions seen in a specialized outpatient clinic at university hospital for the period of the study, the small size hinders extrapolation of data obtained for the Brazilian population. The histopathological examination 
performed by a single professional, although specialized in gastrointestinal pathology, became unable the determination of interobserver concordance rates in the staging of OLGA and OLGIM systems. However, this preliminary study allows an approximate assessment of what is observed in real life. The use of endoscopic examinations with white light devices used on all our patients mimics the reality of endoscopic practice, not only in Brazil but also in countless countries around the world. However, it is undisputed to recognize the progressively increasing role of technological advances in endoscopic examinations as optical filters use $\left(\mathrm{NBI}^{\circledR}\right.$, narrow-band imaging) for image magnification of pre-malignant gastric lesions, with its use already recommended in recent guidelines in the area ${ }^{(49-51)}$. The serological evaluation of gastric atrophy presence through the use of biomarkers, in this study, restricted to a higher age group also constitute limitations of the present study and require future investigations.

In conclusion, the description of histological findings through OLGA and OLGIM staging systems in patients with $H$. pylori chronic gastritis associated with premalignant lesions showed substantial concordance and should be incorporated into daily practice. The simultaneous description of the two systems, OLGA and OLGIM, is more accurate than when described in isolation. The biomarkers PGI, PGI / PGII ratio, and G17, analyzed separately or together, showed low accuracy for diagnosis of premalignant lesions in the studied population. Further studies are needed to validate its use in clinical practice in Brazil.

\section{ACKNOWLEDGMENTS}

The authors would like to thank Maurílio M. Fernandes and Maria de Lourdes M. Fernandes for technical and statistical assistance and also Dr. Jairo Silva Alves, Dr. Ana Flavia Passos Ramos, Karine Sampaio Lima and Raissa Iglesias F A Passos from Instituto Alfa de Gastroenterologia, Hospital das Clinicas UFMG. The authors also thank Eliana Lustosa and Adriano Basques (Laboratório Geraldo Lustosa) for performing the ELISA tests and Biohit for the donation of GastroPanel ${ }^{\circledR}$. LGV Coelho has support from CNPq (Brazil).

\section{Authors' contribution}

Coelho MCF, Coelho LGV and Barbosa AJA contributed to the conception and design of the study; Ribeiro HG, Gomes CGO, and Marinho FP contributed to recruit the patients and collection of the samples; Barbosa AJA and Coelho MCF analysed the biopsies; Coelho MCF and Coelho LGV analysed the data and wrote the paper.

\section{Orcid}

Maria Clara Freitas Coelho: 0000-0001-8028-6114.

Henrique Gomes Ribeiro: 0000-0001-8187-6378.

Celio Geraldo de Oliveira Gomes: 0000-0002-0506-9627.

Frederico Passos Marinho: 0000-0002-0107-3506.

Alfredo J A Barbosa: 0000-0003-3278-8624.

Luiz Gonzaga Vaz Coelho: 0000-0002-8721-7696.

Coelho MCF, Ribeiro HG, Gomes CGO, Marinho FP, Barbosa AJA, Coelho LGV. Gastrite crônica por Helicobacter pylori em pacientes com condições pré-malignas: avaliação dos sistemas OLGA e OLGIM e desempenho de biomarcadores séricos. Arq Gastroenterol. 2021;58(1):39-47.

RESUMO - Contexto - Gastrite atrófica crônica por H. pylori constitui lesão pré-maligna e seu estadiamento de acordo com os sistemas OLGA e OLGIM, visa identificar pacientes com maior risco de desenvolver câncer gástrico e otimizar seu acompanhamento. GastroPanel ${ }^{\circledR}$ é um teste não invasivo composto por painel de biomarcadores séricos incluindo pepsinogênio I (PGI), pepsinogênio II (PGII), gastrina 17 (G17) e anticorpos anti- H. pylori para avaliação de risco de adenocarcinoma gástrico em pacientes com gastrite crônica por H. pylori. Objetivo - Estudo prospectivo para avaliar a concordância entre os sistemas de classificação OLGA e OLGIM, bem como avaliar o desempenho do GastroPanel ${ }^{\circledR}$ em pacientes com lesões pré-malignas secundárias à gastrite crônica por H. pylori no Brasil. Métodos - Pacientes com gastrite crônica por H. pylori portadores de lesões pré-malignas confirmadas por histologia (gastrite atrófica e metaplasia intestinal) foram recrutados no ambulatório de gastroenterologia de um hospital universitário. Todos os participantes foram submetidos a exame endoscópico com biópsias de antro e corpo gástricos analisadas de acordo com o Sistema Sydney atualizado e estadiadas pelos Sistemas OLGA e OLGIM de classificação das gastrites. Amostras de sangue foram coletadas para análise sorológica de biomarcadores (GastroPanel ${ }^{\circledR}$, Biohit, Helsinki, Finlândia). Os valores de corte utilizados para definir pacientes de alto risco para desenvolvimento de câncer gástrico foram os recomendados pelo fabricante: PGI $\leq 30 \mu \mathrm{m}$ e PGI/PGII $\leq 3$. Resultados - Foram recrutados 41 pacientes: 28 mulheres, 13 homens, idade média 67,3 (47-89, DP: 9,6) anos. Pelo sistema OLGA, foram obtidos: OLGA 0 (n=1), OLGA I (n=7), OLGA II (n=17), OLGA III (n=9) e OLGA IV (n=7). Pelo sistema OLGIM, foram obtidos: OLGIM 0 (n=14), OLGIM I (n=5), OLGIM II (n=10), OLGIM III (n=10) e OLGIM IV (n=2). Em relação ao estadiamento histológico entre os pacientes de baixo risco (OLGA/OLGIM 0, I e II) e alto risco (OLGA/OLGIM III e IV) para o desenvolvimento de câncer gástrico, a taxa de concordância encontrada entre as duas classificações foi de $85,4 \%$, com valor kappa=0,678 (IC95\%: 0,440-0,916). Considerando como pacientes de alto risco, aqueles assim estadiados em pelo menos um dos sistemas, a distribuição final de nossa amostra encontrou 24 pacientes de baixo risco e 17 de alto risco para o desenvolvimento de câncer gástrico. Na determinação pelo GastroPanel ${ }^{\circledR}$ para classificação do paciente como de baixo ou alto risco para desenvolvimento de câncer gástrico, PGI mostrou sensibilidade, especificidade e acurácia de 0,47 (IC95\%: 0,26-0,69), 0,67 (IC95\%: 0,47-0,82) e 0,58 (IC95\%: 0,43-0,72), respectivamente, enquanto a razão PGI/PGII mostrou sensibilidade, especificidade e acurácia de 0,06 (IC95\%: 0,01-0,27), 0,83 (IC95\%: 0,64-0,93) e 0,51 (IC95\%: 0,36-0,66), respectivamente. Conclusão - As classificações histológicas OLGA e OLGIM apresentaram taxa de concordância substancial entre si. O uso simultâneo de ambos os sistemas de classificação histológica aumentou a taxa de identificação de pacientes de alto risco para desenvolvimento de câncer gástrico. Os resultados do GastroPanel ${ }^{\circledR}$ não foram eficazes para distinguir pacientes de baixo e alto risco para desenvolvimento de câncer gástrico na população estudada. Mais estudos são necessários para validar seu uso na prática clínica no Brasil.

DESCRITORES - Gastrite atrófica, diagnóstico. Helicobacter pylori. Índice de gravidade de doença. Biomarcadores. Algoritmos. 


\section{REFERENCES}

1. Marshall BJ, Warren JR. Unidentified curved bacilli in the stomach of patients with gastritis and peptic ulceration. Lancet. 1984;1:1311-5.

2. No authors listed. Schistosomes, liver flukes and Helicobacter pylori. IARC Working Group on the Evaluation of Carcinogenic Risks to Humans. IARC Monogr Eval Carcinog Risks Hum. 1994;61:1-241.

3. Suerbaum S, Michetti P. Helicobacter pylori infection. N Engl J Med. 2002;347:1175-86

4. Correa P. Human gastric carcinogenesis: a multistep and multifactorial process - First American Cancer Society Award Lecture on Cancer Epidemiology and Prevention. Cancer Res. 1992:52:6735-40.

5. Wyatt JI. Histopathology of gastroduodenal inflammation. The impact of Helicobacter pylori. Histopathology. 1995;26:1-15.

6. Genta RM, Rugge M. Assessing risks for gastric cancer: new tools for pathologists World J Gastroenterol. 2006;12:5622-7.

7. Ohata H, Kitauchi S, Yoshimura N, Mugitani K, Iwane M, Nakamura K, al. Progression of chronic atrophic gastritis associated with Helicobacter pylori infection increases risk of gastric cancer. Int J Cancer. 2004;109:138-43.

8. Wong BC, Lam SK, Wong WM, Chen JS, Zheng TT, Feng RE, et al. Helicobacter pylori eradication to prevent gastric cancer in a high-risk region of China: a randomized controlled trial. JAMA. 2004;291:187-94.

9. Sipponen P, Kekki M, Haapakoski J, Ihamäki T, Siurala M. Gastric cancer risk in chronic atrophic gastritis: statistical calculations of cross-sectional data. Int J Cancer. 1985;35:173-7.

10. de Vries AC, van Grieken NC, Looman CW, Casparie MK, de Vries E, Meijer GA, et al. Gastric cancer risk in patients with premalignant gastric lesions: a nationwide cohort study in the Netherlands. Gastroenterology. 2008;134:945-52

11. Song H, Ekheden IG, Zheng Z, Ericsson J, Nyrén O, Ye W. Incidence of gastric cancer among patients with gastric precancerous lesions: observational cohort study in a low risk Western population BMJ. 2015;351:h3867.

12. Rugge M, Meggio A, Pennelli G, Piscioli F, Giacomelli G, De Pretis G, et al. Gastritis staging in clinical practice: the OLGA staging system. Gut. 2007;56:631-

13. Capelle LG, de Vries AC, Haringsma J, Borg FT, de Vries RA, Bruno MJ, et al The staging of gastritis with the OLGA system by using intestinal metaplasia as an accurate alternative for atrophic gastritis. Gastrointest Endosc. 2010;71:1150-8.

14. Satoh K, Osawa H, Yoshizawa M, Nakano H, Hirasawa T, Kihira K, et al. Assessment of atrophic gastritis using the OLGA system. Helicobacter. 2008;13:225-9.

15. Marcos-Pinto R, Carneiro F, Dinis-Ribeiro M, Wen X, Lopes C, Figueiredo C, et al. First-degree relatives of patients with early-onset gastric carcinoma show even at young ages a high prevalence of advanced OLGA/OLGIM stages and dysplasia. Aliment Pharmacol Ther. 2012;35:1451-9.

16. Cho SJ, Choi IJ, Kook MC, Nam BH, Kim CG, Lee JY, et al. Staging of intestinaland diffuse-type gastric cancers with the OLGA and OLGIM staging systems. Aliment Pharmacol Ther. 2013;38:1292-302.

17. Coelho LG, Marinho JR, Genta R, Ribeiro LT, Passos MCF, Zaterka S, et al. IV Brazilian Consensus Conference on Helicobacter pylori infection. Arq Gastroenterol. 2018;55:97-121.

18. Malfertheiner P, Megraud F, O'Morain CA, Gisbert JP, Kuipers EJ, Axon AT, et al. Management of Helicobacter pylori infection-the Maastricht V/Florence Consensus Report. Gut. 2017;66:6-30.

19. Samloff IM. Pepsinogens I and II: purification from gastric mucosa and radioimmunoassay in serum. Gastroenterology 1982;82:26-33.

20. di Mario F, Cavallaro LG. Non-invasive tests in gastric diseases. Dig Liv Dis. 2008;40:523-30

21. Iijima K, Sekine H, Koike T, Imatani A, Ohara S, Shimosegawa T. Serum pepsinogen concentrations as a measure of gastric acid secretion in Helicobacte pylori- negative and positive- Japanese subjects. J Gastroenterol. 2005;40:938-44

22. Graham DY, Nurgalieva ZZ, El-Zimaity HM, Opekun AR, Campos A, Guerrero $\mathrm{L}$, et al. Noninvasive versus histologic detection of gastric atrophy in a Hispanic population in North America. Clin Gastroenterol Hepatol. 2006;4:306-14.
23. Bornschein J, Selgrad M, Wex T, Kuester D, Malfertheiner P. Serologica assessment of gastric mucosal atrophy in gastric cancer. BMC Gastroenterol. 2012;12:10.

24. Dinis-Ribeiro M, Yamaki G, Miki K, Costa-Pereira A, Matsukawa M, Kurihara M. Meta-analysis on the validity of pepsinogen test for gastric carcinoma, dysplasia or chronic atrophic gastritis screening. J Med Screen. 2004;11:141-7.

25. Miki K. Gastric cancer screening using the serum pepsinogen test method. Gastric Cancer. 2006;9:245-53.

26. Tong Y, Wu Y, Song Z, Yu Y, Yu X. The potential value of serum pepsinogen for the diagnosis of atrophic gastritis among the health check-up populations in China: a diagnostic clinical research. BMC Gastroenterology. 2017;17:88

27. Leja M, Kupcinskas L, Funka K, Sudraba A, Jonaitis L, Ivanauskas A, et al. The validity of a biomarker method for indirect detection of gastric mucosal atrophy versus standard histopathology. Dig Dis Sci. 2009;54:2377-84.

28. Terasawa T, Nishida H, Kato K, Miyashiro I, Yoshikawa T, Takaku R, et al. Prediction of gastric cancer development by serum pepsinogen test and Helicobacte pylori seropositivity in Eastern Asians: a systematic review and meta-analysis. PloS One. 2014;9:e109783.

29. Syrjänen K. A panel of serum biomarkers $\left(\right.$ GastroPanel $\left.{ }^{\circledR}\right)$ in non-invasive diagnosis of atrophic gastritis. Systematic review and meta-analysis. Anticancer Research. 2016:36:5133-44.

30. Zagari RM, Rabitti S, Greenwood DC, Eusebi LH, Vestito A, Bazzoli F. Sys tematic review with meta-analysis: diagnostic performance of the combination of pepsinogen, gastrin-17 and anti-Helicobacter pylori antibodies serum assays for the diagnosis of atrophic gastritis. Aliment Pharmacol Ther. 2017;46:657-67.

31. Fernández F JI, de Aretxabala UX, Santander DR, Sabah ST, Maira JS, Navarro AR, et al. Detección de lesiones preneoplásicas gástricas mediante niveles séricos de pepsinógeno en población chilena. Rev Méd Chile. 2007;135:1519-25.

32. Fahey MT, Hamada GS, Nishimoto IN, Kowalski LP, Iriya K, Gama-Rodrigues $\mathrm{JJ}$, et al. Ethnic differences in serum pepsinogen levels among Japanese and non-Japanese Brazilian gastric cancer patients and controls. Cancer Detect Prev. 2000;24:564-71.

33. Dixon MF, Genta RM, Yardley JH. Classification and grading of gastritis. The updated Sydney System. International Workshop on the Histopathology of Gastritis, Houston 1994. Am J Surg Pathol. 1996;20:1161-81.

34. Rugge M, Correa P, Di Mario F, El-Omar E, Fiocca R, Geboes K, et al. OLGA staging of gastrites: a tutorial. Dig Liver Dis. 2008;40:650-8.

35. Marques-Silva L, Areia M, Elvas L, Dinis-Ribeiro M. Prevalence of gastric precancerous conditions: a systematic review and meta-analysis. Eur J Gastroentero Hepatol. 2014,26:378-87.

36. Yue H, Shan L, Bin L. The significance of OLGA and OLGIM staging system in the risk assessment of gastric cancer: a systematic review and meta-analysis. Gastric Cancer. 2018;21:579-87.

37. Rugge M, Genta RM, Fassan M, Valentini E, Coati I, Guzzinati S, et al. OLGA Gastritis Staging for the prediction of gastric cancer risk: a long-term follow-up study of 7436 patients. Am J Gastroenterol. 2018;113:1621-8.

38. den Hollander WJ, Holster IL, den Hoed CM, Capelle LG, Tang TJ, Anten MP, et al. Surveillance of premalignant gastric lesions: a multicentre prospective cohort study from low incidence regions. Gut. 2019;68:585-93.

39. el-Zimaity HM, Graham DY, al-Assi MT, Malaty H, Karttunen TJ, Grahan DP, et al. Interobserver variation in the histopathological assessment of Helicobacter pylori gastritis. Hum Pathol. 1996;27:35-41

40. Offerhaus GJ, Price AB, Haot J, ten Kate FJ, Sipponen P, Fiocca R, et al Observer agreement on the grading of gastric atrophy. Histopathology. 1999;34:320-5.

41. Guarner J, Herrera-Goepfert R, Mohar A, Sanchez L, Halperin D, Ley C, et al. Interobserver variability in application of the revised Sydney classification for gastritis. Hum Pathol. 1999;30:1431-4.

42. Isajevs S, Liepniece-Karele I, Janciauskas D, Moisejevs G, Putnins V, Funka K, et al. Gastritis staging: interobserver agreement by applying OLGA and OLGIM systems. Virchows Arch. 2014; 464:403-7 
43. Mera RM, Bravo LE, Camargo MC, Bravo JC, Delgado AG, Romero-Gallo J, et al. Dynamics of Helicobacter pylori infection as a determinant of progression of gastric precancerous lesions: 16-year follow-up of an eradication trial. Gut. 2018;67:1239-46.

44. Coelho LG, Coelho MC. Clinical management of Helicobacter pylori: the Latin American perspective. Dig Dis. 2014;32:302-9.

45. Watabe H, Mitsushima T, Yamaji Y, Okamoto M, Wada R, Kokubo T, et al Predicting the development of gastric cancer from combining Helicobacter pylori antibodies and serum pepsinogen status: a prospective endoscopic cohort study. Gut. 2005;54:764-76.

46. Wang X, Ling L, Li S, Qin G, Cui W, Li X, et al. The Diagnostic Value of Gastrin-17 Detection in Atrophic Gastritis: A Meta-Analysis. Medicine. 2016;95:e3599.

47. McNicholl AG, Forné M, Barrio J, De la Coba C, González B, Rivera R, et al Accuracy of GastroPanel for the diagnosis of atrophic gastritis. Eur J Gastroenterol Hepatol. 2014;26:941-8.
48. Colarossi A, Inga R, Prochazka R, Reyes U, Bussalleu A, Léon-Barúa R. Pepsinógeno y gastrina en el diagnóstico no invasivo de la atrofia gástrica: un estudio caso-control en población peruana. Rev Gastroenterol Peru. 2011;31:110-15.

49. Kato M, Ota H, Okud M, Kikuchi S, Satoh K, Shimoyama T, et al. Guidelines for the management of Helicobacter pylori infection in Japan: 2016 Revised Edition. Helicobacter. 2019;24:e12597.

50. Pimentel-Nunes P, Libânio D, Marcos-Pinto R, Areia M, Leja M, Esposito G, et al. Management of epithelial precancerous conditions and lesions in the stomach (MAPS II): European Society of Gastrointestinal Endoscopy (ESGE), European Helicobacter and Microbiota Study Group (EHMSG), European Society of Pathology (ESP), and Sociedade Portuguesa de Endoscopia Digestiva (SPED) guideline update 2019. Endoscopy. 2019;51:365-88.

51. Banks M, Graham D, Jansen M, Gotoda T, Coda S, di Pietro M, et al. British Society of Gastroenterology guidelines on the diagnosis and management of patients at risk of gastric adenocarcinoma. Gut. 2019;68:1545-75. 